\title{
TEACHING PROCESS GUIDELINE OF INDUSTRY-ORIENTED OFF-CAMPUS INTERNSHIP CURRICULUM FOR TECHNOLOGICAL UNIVERSITY
}

\author{
Hsi-Chi Hsiao', Su-Chang Chen ${ }^{2}$, Jen-Chia Chang ${ }^{3}$, Dyi-Cheng Chen ${ }^{4}$, \\ \& Chun-Mei Chou \\ ${ }^{I}$ Chair Professor, Department of Business Administration, Cheng Shiu University (Taiwan, R.O.C.) \\ ${ }^{2}$ Professor, Department of Marketing and Logistics Management, National Penghu University of Science \\ and Technology (Taiwan, R.O.C.) \\ ${ }^{3}$ Professor, Graduate Institute of Technological and Vocational Education, National Taipei University of \\ Technology (Taiwan, R.O.C.) \\ ${ }^{4}$ Professor, Department of Industrial Education and Technology, National Changhua University of \\ Education (Taiwan, R.O.C.) \\ ${ }^{5}$ Professor, National Yunlin University of Science and Technology (Taiwan, R.O.C.)
}

\begin{abstract}
The off-campus internship curriculum plan should meet the educational goals and the educational philosophy to demonstrate the learning outcomes of the theoretical and practical skills module courses. The purpose of this study is to develop a teaching process guideline of industry-oriented off-campus internship curriculum for technological university. In order to meet this purpose, three parts are proposed. The first part is before internship. The teaching content includes understanding the industry profile, organization and department functions of the internship company, work norms and professional ethics, standard operating procedures, and student internship content. The second part is in the internship. The teaching content includes effective communication, teamwork, technical problem solving strategies, data collection. The last part is after internship. The teaching content includes internship report on the experience of industry-university cooperation. In each stage, this study proposes the teacher should teach the content, the counselor of the industry mentor, and the student needs to complete the content during internship period.
\end{abstract}

Keywords: Teaching process, industry-oriented, off-campus internship curriculum, technical university.

\section{Introduction}

For responding the new generations coming, the Taiwan Ministry of Education emphasizes the plan for the reintegration of colleges and universities resources and provides a variety of operating models for the development of higher education. Therefore, achieving off-campus internships between industry and university is an important part of university students' cultivation (Chen \& Liu, 2018). However, Chen (2018) surveyed off-campus internship courses of 24 department of marketing and logistics management in technological universities in Taiwan found that only 4 schools (14.3\%) said that they had teaching material for off-campus internship courses. The teaching material for off-campus internship courses for technological universities are needed in Taiwan. Chen (2006) said that teaching for the universities in Taiwan had some problems, which were more theoretical knowledge rather than practical skills and the students learn portion rather than integration of the domain field (Hsiao, et al., 2012). Teichler (2000) also indicated that curricula, teaching and learning in the universities should be more applied in practice oriented. Keat et al. (2011) said that the universities must be able to develop and/or design the curriculum to fulfill the demands for the industry. Unfortunately, the curriculum design including instructing method and teaching martial in Taiwan didn't meet with social change and development (Hsiao \& Chen, 2001; Hsiao et al., 2012). So, the off-campus internship curriculum plan should meet the educational goals and the educational philosophy to demonstrate the learning outcomes of the theoretical and practical skills module courses. 


\section{Objectives}

When students during off-campus internship period, what content need to teach? How to teach students? This is the motivation of this study. The purpose of this study is to develop a teaching process guideline of industry-oriented off-campus internship curriculum for technological university.

\section{Methods}

There are two stage of the implementation of this study. First, under group discussed among authors, the draft industry-oriented off-campus internship curriculum goals and teaching process guideline for technological university was developed. Secondly, this study conducted expert meeting to discuss the draft teaching process guideline. There are 5 experts invited to join the meeting. Finally, the industry-oriented off-campus internship curriculum goals and the teaching process guideline was discovered.

\section{Results}

The goals of industry-oriented off-campus internship curriculum are to strengthen professional knowledge of student integrity, to improve student workplace experience, to cultivate student employment competences.

The teaching process guideline of industry-oriented off-campus internship curriculum for technological university includes three parts: before internship, in the internship and after internship.

The first is before internship. In this stage, the teaching content includes understanding the industry profile, organization and department functions of the internship company, work norms and professional ethics, standard operating procedures, and student internship content.

The second is in the internship. The teaching content includes effective communication, teamwork, technical problem solving strategies, data collection.

The last is after internship. The teaching content includes internship report on the experience of industry-university cooperation.

In each parts, this study proposes the teacher should teach the content, the counselor of the industry mentor, and the student needs to complete the content during internship period.

\section{Conclusions and Recommendations}

\subsection{Conclusions}

Under group discussed among authors and expert meeting, the of industry-oriented off-campus internship curriculum goals are found, that is to strengthen professional knowledge of student integrity, to improve student workplace experience, to cultivate student employment competences. The teaching process guideline of industry-oriented off-campus internship curriculum for technological university was discovered. There are three parts for the guideline. That is before internship, in the internship and after internship.

In the before internship parts, the teaching content includes understanding the industry profile, organization and department functions of the internship company, work norms and professional ethics, standard operating procedures, and student internship content. In the internship parts, the teaching content includes effective communication, teamwork, technical problem solving strategies, data collection. In the after internship parts, the teaching content includes internship report on the experience of industry-university cooperation.

\subsection{Recommendations}

Several recommendations are made as follow:

- It is recommended that the planning of teaching content should be further strengthened.

- In order to strengthen the industry orientation, it is recommended to join the business mentors counseling matters.

- In order for students to have compliance content, it is recommended to list the things that students should complete.

- In order to strengthen the theoretical basis of $t$ teaching process guideline, it is recommended to link the problem-base learning theory.

- In order to understand the student's learning situation, it is recommended that the teaching evaluation method should be added in the future. 


\section{References}

Chen, S. C. (2006). Developing a practical competency curriculum for department of marketing and logistics management in technical university. 2006 IEEE International Conference on Service Operations and Logistics, and Informatics: China: Shanghai.

Chen S. C., and Liu C. Y. (2018). The influence of mentoring function, perceived conflict on off-campus internships satisfaction and career choices for penghu technical university's students. 2018 International Symposium on Business and Social Science Singapore. Singapore: Singapore.

Chen S. C. (2018) Curriculum planning, materials development and teaching experiment for integrating off-campus internship and capstone courses in department of marketing and logistics for technological universities: Using project-based learning to cultivate students' skill. Grant project research first year mid-report, Taiwan Ministry of Science and Technology, Grant project number: MOST 106-2511-S-346-001-MY3.

Hsiao, H. C., and Chen, S. C. (2001). Process of curriculum development for engineering education. $2^{\text {nd }}$ Russian Seminar on Engineering Education, UICEE: Tambov, Russia.

Hsiao H. C., Chen S. C., Chang J. C., Chou C. M., Chen C. P., Shen C. H. (2012). Developing and evaluating teaching material for entrepreneurship management course. 2012 Exploring Leadership and Learning Theories in Asia International Conference. Malaysia: Langkawi.

Keat, O. Y., Selvarajah, C., and Meyer, D. (2011). Inclination towards entrepreneurship among university students: An empirical study of Malaysian university students. International Journal of Business and Social Science, VoL.2, No.4, 206-220.

Teichler, U (2000) New perspectives of the relationships between higher education and employment, Tertiary Education and Management, No.6, 79-92. 